\title{
“WHAT IS WORSE THAN DEATH?": EXPERIENCE OF CRITICAL EVENTS AMONG PHYSICIANS
}

\author{
Dalia Antinienè, Žydrūnė Kaklauskaitė \\ Lithuanian University of Health Sciences, Kaunas, Lithuania
}

\begin{abstract}
Background. It is noticeable that doctors' avoidant behavior while dealing with emotional consequences of critical events not only lowers physician's quality of sleep (Kahn, Sheppes, \& Sadeh, 2013), brings them less satisfaction with the results of their work (Gleichgerrcht \& Decety, 2013), but also worsens medical care as they provide poorer services related to the patient (Austin Saylor, \& Finley, 2017; Meier, Back, \& Morrison, 2001). The lack of scientific publications shows that this topic is underresearched and relevant. The purpose of the study is to reveal physicians' experience of critical events.

Methods. Five practicing physicians of anesthesiology-reanimatology and surgery participated in the qualitative part of the research. The data was collected using semi-structured interview and processed using inductive thematic Braun \& Clarke (2006) analysis.

Results. Qualitative analysis revealed the complicated experiences in a physician's workplace, which doctors described as: taking responsibilities in the presence of a patient's death, the risk of burnout and negative emotions experienced after a critical event. The analysis also emerged techniques used in dealing with emotions after critical events and consequences of the latter in one's personal life.

Conclusions. The study revealed that physicians in their work environment come across difficulties such as risk of burnout, balancing between formal and informal communication with patients and emotional strain which is caused by facing a patient's death. Doctors tend to cope with negative emotions that emerge during critical events using various methods, but the most elucidated technique was the avoidance to deal with emotions. Analysis also revealed that experiences, gained through medics' work, modify their attitude towards life and death and change the emotional connection between a physician and his relatives.
\end{abstract}

Keywords: critical incident, death, medical mistake, avoiding emotions, medic.

\section{INTRODUCTION}

$\mathrm{R}$ esearch shows that three quarters of physicians have experienced more than one critical incident during the past five years of practice (Van der Ploeg, Kleber, \& Dorresteijn, 2003). Critical incidents described by medics are mostly related to mistakes, complications, and severe haemorrhage (Cohen, Leykin, GolanHadari, \& Lahad, 2017), deaths of young people and children, suicide, encounters with dead bodies at work (Van der Ploeg et al., 2003; Venytè, 2008; Zdanavičienè, 2013) and unsafe situations.

As it is stated in Conservation of Resources Theory (COR), encounter with critical incidents causes loss of personal resources (self-esteem, sense of security, energy becomes lower). Such encounter not only causes stress, but also aggravates individual's ability to deal with critical incidents. The said theory also maintains that many people are capable of quick recovery of the lost resources and thus deal with the stress created by the critical event. On the other hand, another, Terror Management Theory, that explains what causes and suppresses negative emotions at the moment of encounter with death and realization of mortality, states that culture and relation to the society helps people to manage anxiety and fear that arise when confronted with 
death. It is also noticed that self-confidence and maintaining close relations with other people helps an individual when he or she is encountered with death of another person (Vance, 2014).

In various surveys physicians describe deaths of their patients as critical events (Peters et al., 2013A; Stasiulyte, 2015; Whitehead, 2014). It has been established that, independent of the fact that medical personnel know the deceased, medics experience mourning reactions when a patient dies (Jambois-Rankin, 2000). The results of surveys show that when a physician encounters the death of a patient, the grief of the medic aggravates if the medic had established emotional connection to the patient, had intensely interacted with him or her (Granek, Krzanowska, Tozer, \& Mazzotta, 2012; Meier et al., 2001; Whitehead, 2014;) or if the physician identifies himself or his close ups with the deceased (Whitehead, 2014; Meier et al., 2001).

As qualitative studies reveal, after encounter with death of a patient medical personnel experience such negative emotions as fear, anxiety, hopelessness (Stasiulytè, 2015; Whitehead, 2014), and stress (Barauskaite, 2013). The said physicians are also inclined to reflect the loss, look for their personal fault in the incident (Stasiulyte, 2015; Whitehead, 2014). It has been observed that medics resign with the death of an older person more easily because such death is accepted as natural biological process (Stasiulytè, 2015). Physicians also mention delivery of bad news to the patient as emotionally difficult and stressful or even critical event (Blažyté, 2012).

A tendency has been observed that physicians seek detachment and avoid handling emotions that arise after encounter with critical events (Blažyte, 2012; Stasiulyte், 2015). It has also been established that doctors try to suppress such emotions by relaxing passively or taking care of their own health or health of people close to them (Blaževič, 2016). The other aspect related to the experience of critical events by physicians is the aim to give a meaning to it (Blažytė, 2012; Stasiulytė, 2015). When confronted with death, doctors are inclined to reflect about inevitability of death (Blaževič, 2016; Blažytè, 2012; Stasiulytė, 2015) and feel the desire to discuss the situation with colleagues thus finding comfort and resignation with death (Stasiulyte, 2015).

Medics who encounter pain and suffering of other people are exposed to greater risk of experiencing long-term consequences of such encounters to their psychical health and wellbeing (Melvin, 2015; Zdanavičenè, 2013). It has been observed that doctors who are not capable of recognition and description as well as control of their own negative emotions caused by a critical event are more inclined to experience emotional exhaustion, are more detached emotionally (Gleichgerrcht \& Decety, 2013; Venytè, 2008), they provide poorer services related to patient health care (Meier et al., 2001, Austin et al., 2017), experience less satisfaction with the results of their work (Gleichgerrcht \& Decety, 2013) and lower quality of sleep (Kahn et al., 2013).

Summarizing it can also be maintained that critical events in doctor's work are conceptualized as encounters with deaths of patients, critical conditions, suicides. Two theories explain consequences of such encounters - Conservation of Resources and Terror Management. Physicians in their work quite often encounter critical events that they describe as care of the patient in critical condition or the death of a patient. Such incidents affect medics emotionally, but physicians avoid dealing with emotional reactions that have arisen.

The purpose of the study was to reveal experiences of critical incidents among practicing Lithuanian doctors.

\section{Objectives of the study:}

1. Reveal emotional experiences that physicians encounter during and after critical events.

2. Discuss ways of dealing with emotions that medics apply.

3. Reveal influence of critical incidents on personal life of physicians.

\section{METHODS}

Participants of the study. Five practicing physicians participated in the study, all of them were Lithuanians, and their native language was Lithuanian (see Table 1.) All participants were physicians having no less than five year working experience. The criterion of five years was selected having in mind that individuals will already have been adapted at work and discussions of the subject will cause the minimal risk of secondary trauma. The sufficient working practice to experience critical incidents has also been considered, i.e., five years should be a safe period of time when physicians will have something to share. It was soughed for participants' specializations to be closely related with critical conditions, such as anesthesiology or surgery. Considering that commonness of unique experiences of the participants is very important in qualitative studies other selection criteria were not applied. 
Table. Demographic characteristics of participants of the qualitative study

\begin{tabular}{|c|c|c|c|c|c|}
\hline & Linas* & Agnë* & Karolis* & Greta* & Ignas* $^{*}$ \\
\hline Specialization & $\begin{array}{c}\text { Physician } \\
\text { reanimatologist- } \\
\text { anesthesiologist }\end{array}$ & $\begin{array}{c}\text { Physician } \\
\text { reanimatologist- } \\
\text { anesthesiologist }\end{array}$ & $\begin{array}{c}\text { Physician } \\
\text { surgeon- } \\
\text { traumatologist }\end{array}$ & $\begin{array}{c}\text { Physician therapist } \\
\text { (working in an } \\
\text { emergency room) }\end{array}$ & $\begin{array}{c}\text { Physician } \\
\text { neurosurgeon }\end{array}$ \\
\hline
\end{tabular}

Note. *For the purpose of anonymity, names of the participants have been changed.

The participants were invited to take part in the study using the method of snow ball. The method was chosen considering the fact that the research aimed to involve participants who had experience that was relevant to the issue (Žydžiūnaite \& Sabaliauskas, 2017). Also, it was more likely that the involved individuals would be motivated to share their experiences. Those participants of the research who responded were motivated to participate, reflective, open, therefore the material obtained during the interview was deep and contained sentimental material.

The Process of the Study. Bioethics Committee of the Lithuanian University of Health Sciences on June 6, 2017 issued permission (No. BECSP(M)-135) to perform the study. The research was conducted from July 6, 2017 till August 14, 2017. Meetings with the participants were held at convenient for them time in a convenient location. Meetings with three participants were conducted in their workplace as they requested. One participant was interviewed in a quiet café, so there were no disturbances, another participant requested to have a meeting at his home. All five interviews were conducted smoothly.

Before the interview, the participants of the study were acquainted with the conditions of the survey (anonymity, possibility to withdraw from the study, usage of the interview material, etc.). After receiving consent of the participant to take part in the research he or she was requested to fill in the informed consent form. The interview lasted from 13 to 39 minutes.

Transcription was done by the researcher, therefore it was possible to stay close to the material and the experience of participants and get deeper understanding of the phenomena. Transcription and review of the transcribed material also allowed to easier perform division of the available material into notional units and codes.

Analysis of the Data. Analysis of the data was performed applying inductive theme analysis of Braun and Clarke (2006). The aim of theme analysis is to determine, analyze, and present themes that emerge when studying a particular phenomenon. The method of theme analysis was selected because it allows the researcher to distance from the theoretical field and construct themes based only on the obtained information (Braun \& Clarke, 2006). The said method is also a widely used and described in literature on method of qualitative data analysis, which does not require thorough theoretical background of the researcher or accumulated significant experience in the field of qualitative studies (Žydžiūnaitè \& Sabaliauskas, 2017).

To ensure validity of the research, data were also reviewed by a consultant and scientific advisor, accuracy of formulations was discussed, they were adjusted to reflect experiences of the participants of the study more accurately. The researcher also kept a diary during the entire period of qualitative study.

\section{RESULTS}

When performing thematic analysis, it was sought to distinguish themes that were common to the majority of the participants of the research and described the experience of critical events in the work of a physician. Three major themes emerged: complicated experiences in the work of a physician, techniques of dealing with emotions after the critical event, and consequences critical events has for one's personal life. Theme analysis results are presented in a scheme (see Figure).

\section{Complicated experiences in the work of a physician}

All physicians who participated in the research distinguished experience of complicated situations that has long lasting effect. The participants stated that critical events and work with patients in critical condition have become an ordinary part of their work, but the necessity to draw the line between formal and informal contact with 
patients always remains. However, all physicians admitted that when confronted with critical event they experience negative emotions. Medics also talked about taking responsibility when the patient dies and the danger of professional burnout that arises because of enormous workload. Each of the subthemes is discussed in more detail below.

1.1 Critical events and critical conditions ordinary part of work. The participants distinguished that, despite the fact that people of many professions encounter mistakes in their work, errors made by physicians are equivalent to critical events because of the damage they cause: " $<\ldots>$ it looks like a critical incident. (Hm) though I do not know if a failure could be attributed to a critical incident. (Hm) in other words, if someone suffers because of my ... actions." (Linas, 2). The participants of the study also indicated that they often encounter patients in critical condition, therefore they consider critical events to be a part of their everyday professional life: "In that sense, no, well [critical incidents] should be (sighs), well, I say, it is work and it must be done, in the sense, you must have such attitude <...>" (Ignas, 24). One of the participants of the study emphasized that with the work experience a person gets used to critical events when it seems that there is nothing that could surprise: " $<\ldots>$ may be it sounds rude when half of a person's head or body is missing, it means nothing to me (hm), this does not affect me $(\mathrm{hm})$, I feel no pain, I have seen all that and I do not know what new could be in it." (Karolis, 82).

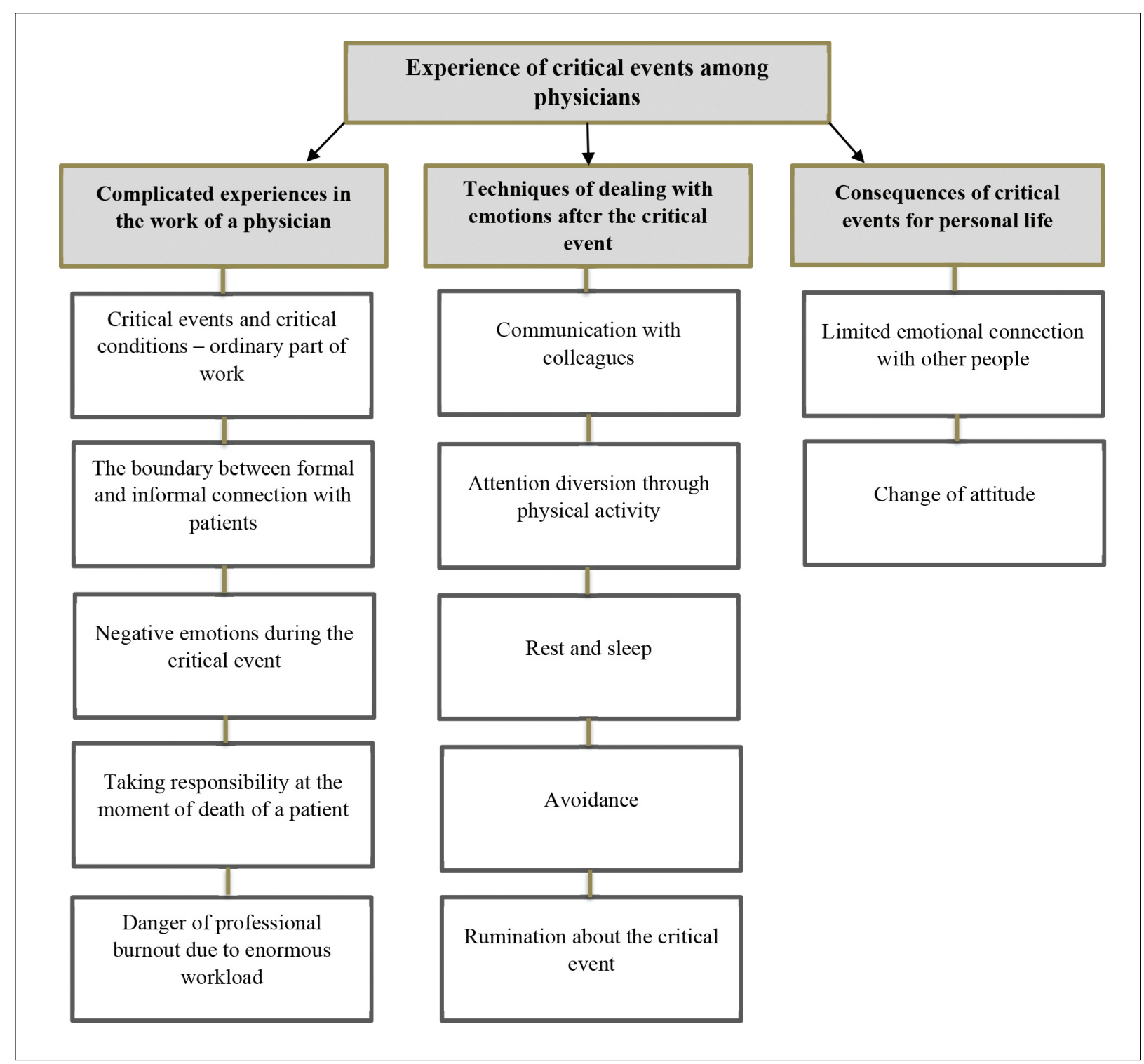

Figure. Results of thematic analysis: Major themes and subthemes 
1.2. The boundary between formal and informal connection with patients (5/5). The problem of contact with patients in the work of a physician emerged during the interview. The participants of the research told that with some patients they maintain closer contact than with the others: "In that sense, I say, a certain connection with the patient emerges; somehow this happens with some patients, but does not happen with the others. You just feel more pity about some while about others (smiles) I cannot say that I do not feel sorry, but I do not." (Linas, 97). Physicians also talked about the fact that critical events, when death is imminent, and patients are young cause greater sorrow: " $<\ldots>$ older age [patient], but not the sudden deterioration, (inhales) and there he was well and still can be well, and then you care more (silently). That concern, you care equally about the one and the other, but that concern you feel deeply in the latter case." (Agne, 43-44). However, one of the participants claims having learned to feel no emotions towards the patient and says he is using it as a safety mechanism: "(pause, ponders). Those as I say that I that I would something empathize with each in that sense further <...>”. (Ignas, 17). On the other hand, the internal suffering of a physician when observing a dying patient who suffers from pain emerged: "But, well, Lithuanian law does not let us help to depart. (Hm) Only to make the departure easier. $<\ldots>$ Well, then you make it easier for him and for yourself by giving, well, medication. Some makes him sleepy, some relieve pain, some makes him lose consciousness, say, the same morphine." (Agnè, 72-75).

1.3. Negative emotions during the critical event (5/5). When speaking about emotions during the critical incident all participants of the study admitted that they experienced certain feelings anger, guilt, anxiety. The anger of medics, which arises because of insufficient help was particularly obvious: "(pause, tries to suppress tears) At that time? (hm). (inhales) At that time perhaps the greatest irritation was because I cannot get help that I had been expecting from the surrounding personnel." (Agnè, 8-9). Some medics admitted that critical event causes anger, which is mixed with the feeling of guilt: " $<\ldots>$ maybe you feel some guilt when you think that perhaps you have done something wrong. <...> Maybe you feel some anger $(\mathrm{hm})$ that perhaps you should have tried harder, maybe you had something more <...>, so, it's anger $>$ " (Linas, 78-79). Medics also have admitted that they feel anxiety when confronted with the critical event, which arises because of time limitations and insufficient information about the general condition of the patient: "Yeah, that anxiety is caused $(\mathrm{hm})$ that that you have short time to make that that person should survive. $<\ldots>>$ And that lack of time there causes that anxiety." (Greta, 41). Medics told about feelings of self-reproach and guilt after the critical incident with unsuccessful outcome: " $<\ldots>$ such musing, $<\ldots>$ pity arises a bit, $<\ldots>$ a bit of self-accusation $<\ldots>$, but, well, it's a short signal and that's all." (Karolis, 47).

1.4. Taking responsibility at the moment of death of a patient (5/5). All physicians who participated in the research shared the suppressing experience when they have to witness the death of a patient. They emphasized that such encounter with death is the most critical part of their work: "That is, say, the most critical in our work perhaps is the death (hm) of a patient. <...> what is worse than death?" (Linas, 4-5). The participants of the study said that, when the condition of the patient is particularly complicated, death quasi frees from suffering, but death to the medic himself causes ambivalent feelings - it both saddens and cheers because sufferings of another person are over: " $<\ldots>$ then you think that the other person is relieved. $(\mathrm{hm})$ Well, it's possible that sometimes you are happy that the person has peacefully departed, as peacefully as possible. Because at other times, yeah, you see a person so exhausted and used-up that, well, death for him is not the worst outcome." (Agne, 66-67). The participants of the study deaths of young people and sudden departures from life distinguished as having the greatest psychological burden to a medic: "There are such things, and deaths have occurred, say, of young people, (hm) that seem not to have so occurred, but occurred, so, well, such things." (Ignas, 7).

1.5. Danger of professional burnout due to enormous workload (4/5). The participants of the study also talked about enormous workloads that cause overwork and aggravate their professional activities. They distinguished that striving for financial well-being and wishing to afford more than an average person they are forced to take several jobs: ,,_..> nowhere in the world doctors don't have to work two or three jobs. $<\ldots>$ say, after twelve years of studies we wish, well, to live a little better than, well, say some average person <...>” (Karolis, 64). However, working in several jobs does not leave them time for rest: "Well, I mean 
that perhaps working at such pace when you don't have a possibility to rest after the night shift [you get tired] <...>"(Greta, 19). Therefore, to maintain their psychological health, medics are trying to emotionally distance themselves from work: "Welll (drags) at least I imagine that one should try doing this [to distance from work]. $\langle\ldots\rangle$ because I say that here for each [patient] here... you will become nuts (laughs)." (Ignas, 20). Immense workload, specifically, causes overwork and professional burnout that affects many spheres of life: "They are overworked, burnt out, they come and think that will have to somehow work it off, because they know that after these twenty-four hours they will have to go to another workplace or maybe they will have to go home where, I don't know, maybe a child, mother or someone else is sick, so these problems go on and on and on and here is no time for rest." (Linas, 117).

\section{Techniques of dealing with emotions after the critical event}

In conversations with the participants of the study the necessity to deal with emotions that arise after the critical incident emerged. Physicians mentioned communication with colleagues, physical activity, rest and sleep, humor and rumination about the critical experience as techniques for dealing with the said emotions. The subtheme of avoidance to deal with arising emotions was distinguished in particular.

2.1. Communication with colleagues (4/5). The participants of the study named conversations with colleagues as one of the most efficient techniques of dealing with emotions after the critical event. Stories of the physicians showed that the most effective possible help to themselves is discussion of critical experience with a colleague: "Maximum what you can possibly do is perhaps with co-workers. (hm) To share impressions, to speak out (smiles). Maybe as much (whispers)." (Agne, 30). Doctors maintain that after such conversations they feel calmer and relieved: "Then it seems such, wow, relief (gesticulates), if I did that, (hm) and the other person would have done exactly the same, that means I haven't done anything wrong." (Linas, 38).

2.2. Attention diversion through physical activity (3/5). Some physicians named active physical actions as one of emotion control techniques. According to them, sport or other activity helps "escaping" from thoughts: " $<\ldots>$ wanted, well, somehow to forget, to somehow waive thoughts away, it was bicycle, well, to go somewhere to work out $<$...>." (Karolis, 85). Medics also attest that they try to ventilate emotions through active actions in a workplace as well, but conditions for that are not always favorable: "(ponders) Sit ups, some physical activity. Muscle activity. <...> Hm. If there is a possibility to do this." (Greta, 14). Finally, leaving the home environment was named as a method for dealing with emotions that have arisen: " $<$...> maybe even meeting with somebody, simple pastime <...>." (Linas, 93).

2.3. Rest and sleep (4/5). When speaking about dealing with negative emotions after the critical incident medics noted that sometimes after the working day they experience emotional paleness because of the lack of energy. In such cases they resort to sleep: "You see the door of your house, see the pillow (laughs) and think: My God, this is it. I mean, everything switches off." (Karolis, 86). Physicians maintain that when they feel emotionally bad after the critical incident first of all they try to get some sleep: "So far I have no problems with sleep, so after sleeping I feel somewhat better." (Greta, 17). Medics also note that any activity that allows to have rest also helps to control thoughts: " $<\ldots>$ you try, I don't know, to simply rest somewhere, good sleep, rest $<\ldots>$ helps somehow dissipate these thoughts <...>." (Linas, 92).

2.4. Avoidance (5/5). One particularly distinguished subtheme was related to avoidance of dealing with emotional experience and hiding the said emotions from the surrounding people. Some physicians maintained that their emotions could be easily transferred to colleagues and thus aggravate their work as well as reduce productivity: "I have them, these emotions, but I have no right to show them to employees as my emotions would impede their work." (Greta, 10). They also noted that experience of emotions would hinder concentration on work and would increase the risk of mistakes: "(ponders, smiles) Well, those emotions, I say, well are not many, so that you would start running <...> you are trying to think how in a certain situation what you have to do right (inhales)." (Ignas, 28). Physicians also talked about absence of emotions when confronted with the critical event, as if clear mind and the necessity to act would limit their emotional expression at that moment: "When you see that patient everything disappears $<\ldots>$ 
you see only one thing, can you or cannot give him [help], you have to do something. (hm) then at that moment those feelings and emotions are absolutely absent." (Karolis, 40). Finally, trying to avoid emotions related to the health of a patient medics admitted that they seek to distance themselves from the patient and be as little as possible emotionally involved at work: "So, it's not accidental that we somehow, as [names another person] said, and as I say, build a wall. I can't see, I can't hear, I just do what is needed." (Linas, 17). It is worth noting that one of the participants of the research admitted that at the beginning of his carrier he did not avoid to deal with emotions with the help of alcohol: "it seemed to me that this [alcohol consumption] was a way to relax, it's like restarting your brain $(\mathrm{hm})$, well, when you inebriate, everything seems funny, easy $<\ldots>$ " (Linas, 90-91), but after having noticed the harm it causes he claims he had quit the habit.

2.5. Rumination about the critical event (5/5). All physicians who participated in the research admitted that after critical events with unsuccessful outcome they quite often get stuck into thinking and thoughts about it and look for their own mistakes, though there had been none: "That perhaps I haven't done something. ( $\mathrm{hm}$ ) though most often in such situations you don't even need to look for those mistakes, $<\ldots>$ but, here, at that moment such first thoughts that something I have done wrongly <...>." (Linas, 74). Medics also indicated that after the critical condition of a patient they analyze and review their own work: "Well, what else I could have done, what I have done wrong, what I could have done faster, what I couuuuuld have done differently." (Agnè, 18). Physicians admit that when they fail to save life they often encounter an "internal executioner" that makes them rethink their own actions: "if, save God, it happens so that, well, you fail, you know, (hm) that that life, well, it's no fun, then you maybe sit and think $<\ldots . .>$." (Karolis, 43).

\section{Consequences of critical events for personal life}

All medics who participated in the qualitative study indicated that they feel consequences of critical incidents for their personal life. The said change is characterized by limited emotional contact with relatives or other surrounding people and by change of attitude, which had been developed when they started the clinical practice.
3.1. Limited emotional connection with other people. During the interview physicians talked about limited emotional contact with other people - both with the close ups and colleagues as well as with patients. According to them, to provide quality help to a person they are forced to hide their emotions, and quite often this tendency remains in socializing with people of the close environment: "<...> that, well, perhaps, say, professionally here some mask is put on $<\ldots>$ (hmmm), well, like you forget to take this mask off that you put on, say, at work, (hm) and maybe it is harder for the surrounding people to decide about my emotional state." (Greta, 47). Physicians also admitted that after work they encounter unpredictable reaction of relatives to their emotional state: "(pause) either understand or are angry that you are such. (laughs)" (Agnè, 57). The consequence of all such difficulties is that medics feel isolated and unable to share their emotional experiences with the surrounding world: "(sighs) Right now I don't know. If if, say, looking at me if I wanted to tell someone about my feelings, what do I feel, then yes, then it's bad. I don't know/I am unable to tell this to someone (Linas, 122).

3.2. Change of attitude. When speaking about their working experiences physicians described their changed philosophy of life and attitude towards such natural processes of life as death. When they started their clinical practice they began to view the death as part of life and pay less significance to it: " $<\ldots>$ just you accept everything in perhaps a more natural way $\langle\ldots\rangle$, well, that there is a life circle, (hm) someone is born, someone dies, someone gets ill, someone..." (Agnè, 82). Medics also states that they have learned to accept some events in life as inevitable: " $<\ldots>$ if time has come for a person to die, he will die <...>." (Greta, 51); "such various situations you see, well, you start to think that in that sense, well, be as it may $<\ldots>$ if something happens, it will have to be so and that's all." (Ignas, 42). Their attitude towards people close to them has also changed, physicians claim that they have become more attentive: " $<$... y you become very cautious. You protect everyone $<$... $>$, don't take that, you may choke, don't touch that, you may get burned there <...>." (Linas, 101). But physicians agree that due to their work they have become tougher, the work has hardened them: " $<\ldots>$ they perhaps may harden me. (hm) Harden and maybe next time in the same situation I maybe, 
I don't know, I will feel somewhat braver <...>." (Karolis, 118).

Thus in summary it may be stated that physicians at their work encounter several difficulties, such as the need to balance on the verge of formal and informal contact with the patient, danger of professional burnout because of the workload and psychological burden that is caused by encounter with the death of a patient. Physicians also note that in their work they often encounter critical incidents, which they view as a normal part of their work and which cause a lot of negative emotions. As to the negative emotions that arise after critical events, physicians named several ways of how they handle them - sleeping, diverting attention by active actions, socializing with colleagues, and ruminating about the situation. However, during the interview the aim of doctors to avoid emotions and dealing with them became the most obvious. Finally, it was revealed that critical incidents affect physicians' their attitude towards life and death and connections with other people, which become emotionally poorer.

\section{DISCUSSION}

As it turned out during the qualitative study, physicians assign deaths of patients and their own mistakes that cause complications to patient's health to critical incidents. These results conform to the data in the literature, which reveals that both Lithuanian and foreign medics mention deaths of patients as the most critical incidents in their work (Blažytė, 2012; Jambois-Rankin, 2000; Peters et al., 2013A; Stasiulyte, 2015; Whitehead, 2014). It is also observed in the studies that medical personnel claims having enough information, which allows to adequately communicate with the dying patient but communicating with relatives of the dying person causes stress, and physicians estimates their ability in this area as poorer (Peters et al., 2013B). It has turned out that quite often the most critical incident is not the death of a patient itself, but inadequate emotional reaction of relatives that is affecting the physician.

All participants of the study spoke about the experience of the death of a patient and emotions that arise upon the encounter with it. They indicated that upon the encounter with the critical event such emotions as anger, guilt and anxiety arise. These results add to the data obtained in other studies, which show that besides the mentioned emotions physicians quite often experience fear and hopelessness (Stasiulyte, 2015; Whitehead, 2014). In scientific studies it is also observed that it is easier for medics to accept the death of an older person, which seems to be "natural" (Stasiulytè, 2015). These results are supplemented by data obtained in the present study. One of the participants of the research told that deaths of young people and such deaths that are unexpected or a given development of the illness is not common are the most critical experiences that shock the most. All participants of the study also spoke about painful experiences when, after having established emotional connection with the patient, it was particularly difficult for them to accept his death. Physicians told that quite often they experience pain and internal suffering that has been caused by the scene of a patient dying in pain. One participant of the study told about ambivalent feelings that arise when a suffering person finally dies. She admitted feeling relief, which is mixed with sadness. The obtained data in the present study supplement the available scientific literature. Studies find that when a doctor establishes contact with the patient, communicates with him or her often or identifies himself with him or her or identifies his close relatives with the said patient in case of death of the patient the physician's mourning aggravates (Granek et al., 2012; Meier et al., 2001; Whitehead, 2014).

In literature when describing techniques of dealing with emotions that arise in the critical incident it is distinguished that physicians after the critical incident are inclined to ruminate and ponder about critical incidents (Stasiulyte, 2015; Whirehead, 2014), take rest and relax by engaging into physically passive activity (Blaževič, 2016), communicate with colleagues (Stasiulytè, 2015), and avoid dealing with emotions as well as to distance themselves from them (Blažytė, 2012; Stasiulytè, 2015; Van der Ploeg et al., 2003). These dealing with emotions techniques were also distinguished by medics who participated in the research and supplemented them by choosing physical activity as a technique of dealing with emotions. The aim of medics to avoid dealing with arising emotions was the most obvious. Participants of the study maintained that to properly perform their work and to prevent the felt emotions from affecting their colleagues they are forced to deny or distance themselves from the felt emotions, not enter into very close contact with patients or colleagues. On 
the other hand, when striving to distance themselves they feel left alone with their feelings.

Those experiences when medics feel lonely and unwanted leave trace in their personal lives. Participants of the study indicated that their work as physicians has changed their connection with close ups. Physicians said that because of the need to distance themselves from emotions at work they do not feel capable of both recognizing the experienced emotions and communicating with people who are close to them. During the interview it also became obvious that critical events have changed their attitude towards death and life itself all participants of the study claimed having realized the inevitability of some events and viewing death as a natural part of life. The same tendency was observed in other studies which acknowledged that encounter with critical events makes physicians ponder about the fragility of life and inevitability of death, and this changes their world view (Blaževič, 2016; Blažytė, 2012; Stasiulytė, 2015). Thus they try to give a sense to life and create basis for something, which is out of their control (Blažyte, 2012; Stasiulyte, 2015). Therefore, data of the present qualitative study closely correlate with and supplement results of other studies.

\section{CONCLUSIONS}

1. Medics name death of patients and experiences of their own mistakes that generate the whole spectrum of difficult, negative emotions to them as critical incidents. Medics also have to navigate between formal and informal relationship with patients, they feel responsibility at the moment of death of a patient, and all these experiences as well as big workload increase the risk of professional burnout of physicians.

2. Physicians deal with emotions that arise during the critical incident applying such methods as active actions, conversations with colleagues, rest and sleep as well as rumination about the critical incident. However, the aim of medics to deny and to distance themselves from experienced negative emotions has emerged as the most obvious.

3. Critical incidents leave trace in the personal life of physicians, which they feel through poor connection to people close to them and through the change of attitude towards death and life.

Conflict of interests. The research was not funded by any organization or company.

\section{REFERENCES}

Austin, C. L., Saylor, R., \& Finley, P. J. (2017). Moral distress in physicians and nurses: impact on professional quality of life and turnover. Psychological Trauma: Theory, Research, Practice, and Policy, 9(4), 399-406.

Bamberger, P. A. (2005). Work-based critical incidents and problem drinking. Work and Occupations, 32(3), 257289. https://doi.org/10.1177\%2F0730888405277900

Barauskaite, V. (2013). Streso ir ,,perdegimo “ sindromo paplitimas tarp skirtingo profilio slaugytoju (Magistro baigiamasis darbas). Kaunas: Lietuvos sveikatos mokslų universitetas.

Blaževič, B. (2016). Slaugytojų požiūris ị mirštantị pacientą (Magistro baigiamasis darbas). Kaunas: Lietuvos sveikatos mokslų universitetas.

Blažyte, V. (2012). Gydytojo pasirengimas, atsakomybe ir emocine patirtis pranešant bloga žiniq pacientui (Magistro baigiamasis darbas). Vilnius: Vilniaus universitetas.

Braun, V., \& Clarke, V. (2006). Using thematic analysis in psychology. Qualitative Research in Psychology, 3, 77-101. https://doi.org/10.1191/1478088706qp063oa

Cohen, R., Leykin, D., Golan-Hadari, D., \& Lahad, M. (2017). Exposure to traumatic events at work, posttraumatic symptoms and professional quality of life among midwives. Midwifery, 50, 1-8. https://doi. org/10.1016/j.midw.2017.03.009

Gleichgerrcht, E., \& Decety, J. (2013). Empathy in clinical practice: How individual dispositions, gender, and experience moderate empathic concern, burnout, and emotional distress in physicians. Empathy in Clinical Practice, 8(4). https://doi.org/10.1371/journal.pone.0061526

Granek, L., Krzyzanowska, M. K., Tozer, R., \& Mazzotta, P. (2012). Difficult patient loss and physician culture for oncologists grieving patient loss. Journal of Palliative Medicine, 15(11).

Jambois-Rankin, K. R. (2000). Critical incident stress debriefing: An examination of public services personnel and their responses to critical incident stress. Illness, Crisis \& Loss, 8(1), 71-90.

Kahn, M., Sheppes, G., \& Sadeh, A. (2013). Sleep and emotions:Bidirectionallinksandunderlyingmechanisms. International Journal of Psychophysiology, 89(2), 218228. https://doi.org/10.1016/j.ijpsycho.2013.05.010

Meier, D. E., Back, A. L., \& Morrison, R. S. (2001). The inner life of physicians and care of the seriously ill.JAMA, 286(23), 3007-3014. doi:10.1001/jama.286.23.3007 
Melvin, C. (2015). Historical review in understanding burnout, professional compassion fatigue, and secondary traumatic stress disorder from a hospice and palliative nursing perspective. Journal of Hospice and Palliative Nursing, 17(1), 66-72. doi: 10.12691/ajnr-6-3-1

Peters, L., Cant, R., Payne, S., O`Connor, M., McDermott, F., Hood, K., ... Shimoinaba, K. (2013B). Emergency and palliative care nurses' levels of anxiety about death and coping with death: A questionnaire survey. Australasian Emergency Nursing Journal, 16, 152-159. https://doi.org/10.1016/j.aenj.2013.08.001

Peters, L., Cant, R., Payne, S., O’Connor, M., McDermott, F., Hood, K., ... Shimoinaba, K. (2013A). How Death Anxiety Impacts Nurses' Caring for Patients at the End of Life: A Review of Literature. The Open Nursing Journal, 7, 14-21. https://dx.doi.org/10.2174\% 2F1874434601307010014

Stasiulytè, A. (2015). Gydytojo patyrimas susidūrus su paciento mirtimi (Magistro baigiamasis darbas). Vilnius: Vilniaus universitetas.

Vance, L. M. (2014). Death anxiety and the relational. Journal of Humanistic Psychology, 54(4), 414-433. https://doi.org/10.1177\%2F0022167813507631
Van der Ploeg, E., Kleber, S. M., \& Dorresteijn, R. J. (2003). Critical incidents and chronic stressors at work: Their impact on forensic doctors. Journal of Occupational Health Psychology, 8(2), 157-166. doi: 10.1037/1076-8998.8.2.157

Venytè, R. (2008). Emociniu sunkumy priežastys ir ju kontrolès galimybès terminalinès büklès pacientus prižiūrinčiu slaugytoju darbe (Magistro baigiamasis darbas). Kaunas: Lietuvos sveikatos mokslų universitetas.

Whitehead, P. R. (2014). The lived experience of physicians dealing with patient death. BMJ Supportive and Palliative Care, 4, 271-276. doi: 10.1136/ bmjspcare-2012-000326

Zdanavičienè, D. (2013). Greitosios medicinos pagalbos darbuotoju darbo organizavimo ypatumu juertinimas (Magistro baigiamasis darbas). Kaunas: Lietuvos sveikatos mokslų universitetas.

Žydžiūnaitè, V., \& Sabaliauskas, S. (2017). Kokybiniai tyrimai: Principai ir metodai. Vilnius: Leidykla VAGA. 